\title{
BIOASSAY ASSESSMENT OF METARHIZIUM ANISOPLIAE (METCHNIKOFF) SOROKIN (DEUTEROMYCOTA: HYPHOMYCETES) AGAINST ONCOMETOPIA FACIALIS (SIGNORET) (HEMIPTERA: CICADELLIDAE)
}

\author{
Wolney Dalla Pria Júnior¹; Paulo Teixeira Lacava²*; Claudio Luiz Messias³ ;oão Lúcio Azevedo²; \\ Pedro Magalhães Lacava ${ }^{1}$
}
'Departamento de Bioquímica, Universidade Estadual Paulista “Júlio de Mesquita Filho", Araraquara, SP, Brasil; ${ }^{2}$ Departamento de Genética, Escola Superior de Agricultura “Luiz de Queiroz”, Universidade de São Paulo, Piracicaba, SP, Brasil; ${ }^{3}$ Departamento de Genética e Evolução, Universidade Estadual de Campinas, Campinas, SP, Brasil.

Submitted: October 05, 2006; Returned to authors for corrections: July 22, 2007; Approved: January 19, 2008.

\begin{abstract}
Citrus Variegated Chlorosis (CVC) is an economically important, destructive disease in Brazil and is caused by Xylella fastidiosa and transmitted by sharpshooter insects. In this study, the efficacy of the fungus Metarhizium anisopliae in controlling the sharpshooter Oncometopia facialis was studied by bioassay conditions. In the bioassay, insects were sprayed with a suspension containing $5 \times 10^{7}$ conidia $\mathrm{mL}^{-1}$. Adults captured in the field were treated in groups of 10 in a total of 11 replications per treatment. Significant differences between the natural mortality and the mortality of insects treated with the fungus were observed 6 days after inoculations $(P<0.05)$. These significant differences increased until 10 days after treatment. The fungus caused $87.1 \%$ mortality, with the $\mathrm{LT}_{50}$ varying from 5 to 6 days. The $\mathrm{LC}_{50}$ was $1.2 \times 10^{6}$ conidia $\mathrm{mL}^{-1}$, varying from $7.7 \times 10^{5}$ to $2 \times 10^{6}$ conidia $\mathrm{mL}^{-1}$. The results showed that the sharpshooter $O$. facialis was susceptible to the entomopathogenic action of $M$. anisopliae in controlled condition during bioassay.
\end{abstract}

Key words: microbial control, entomopathogen, Citrus Variegated Chlorosis (CVC), bioassay

\section{INTRODUCTION}

The entomopathogenic fungus Metarhizium anisopliae (Metschnikoff) Sorokin has been isolated from many insect species including the orders Lepidoptera, Coleoptera, Orthoptera and Hemiptera $(6,34)$. M. anisopliae is used commercially in Brazil to control the sugar cane spittlebug, Mahanarva posticata (Homoptera: Cercopidae), and it is also used in other countries, including Colombia, Australia and the U.S.A. to control a variety of pests. The wide insect host range of the genus Metarhizium makes it commercially attractive as a biocontrol agent (24). Excessive use of conventional chemical insecticides has resulted in pest resistance, elimination of economically beneficial insects, residue persistence in the environment, toxicity to humans and wildlife, and a higher cost of crop production (22).
Xylella fastidiosa is a fastidious Gram-negative, xylemlimited bacterium $(5,30)$. Specific strains cause diseases in many crops of economic importance, such as grape, almond, peach, coffee, plum and citrus $(12,15-17,25,30)$. In Brazil, the most economically important disease caused by $X$. fastidiosa is Citrus Variegated Chlorosis (CVC) $(15,31)$. In Brazil, over 70 million sweet orange trees $(38 \%)$ are affected annually. CVC is responsible for losses of US\$ 100 million per year to the Brazilian citrus industry and affects all commercial sweet orange varieties $(7,8)$. X. fastidiosa is disseminated rapidly from the use of infected nursery trees and transmission of $X$. fastidiosa by several xylem-feeding sharpshooter insect vectors (4).

The insect vectors that transmit $X$. fastidiosa to plants are leafhoppers of the subfamily Cicadellinae (Hemiptera: Cicadellidae), known as sharpshooters. In citrus plants, Oncometopia facialis (Hemiptera: Cicadellidae: Cicadellinae)

*Corresponding Author. Mailing address: Departamento de Genética, Escola Superior de Agricultura "Luiz de Queiroz", Universidade de São Paulo, Caixa Postal 11 - Caixa Postal 83. 13400-970, Piracicaba, SP, Brasil. Tel.: (+5519) 3429-4251, Fax: (+5519) 3433-6706. E-mail: ptlacava@esalq.usp.br 
is the principal vector of the bacterium $X$. fastidiosa (28). The principal means of controlling this vector has been the use of chemical insecticides $(34,35)$ with consequent ecological problems.

In developing effective replacements for toxic chemicals, entomopathogenic fungi have been considered as an alternative (29). Adoption of a biological control agent, such as Metarhizium, in integrated pest management (IPM) often results in overall reduction in the total amount of pesticide applied (26).

The aim of this study was to investigate the efficacy of the entomopathogenic fungus $M$. anisopliae to control the sharpshooter $O$. facialis under conditions of bioassay in citrus plants.

\section{MATERIALS AND METHODS}

\section{Strain of M. anisopliae}

We used strain $\mathrm{E}_{9}$ of $M$. anisopliae var. anisopliae, isolated from Deois flavopicta (Hemiptera:Cercopidae), obtained from a stock collection of the Department of Genetics and Evolution, Universidade Estadual de Campinas, Campinas, São Paulo, Brazil. This strain is largely used in bioassays and genetic studies $(9,11,20,23,32)$. The conidia used in these studies were producted on complete culture medium (CM) consisting of yeast extract, glucose, minerals, agar, and water, according to Alves et, 1998 (3). The $\mathrm{E}_{9}$ strain was plated on Petri dishes containing $\mathrm{CM}$ and incubated in a B.O.D. chamber at $27^{\circ} \mathrm{C} \pm 1^{\circ} \mathrm{C}$ for 6 to 7 days.

\section{Insects}

Adults of $O$. facialis were collected from orchards of sweetorange (Citrus sinensis [L.] Osbeck cv. pera) containing CVCsymptomatic orange trees in Araraquara, São Paulo, Brazil. The insects were carefully transported from the field to cages. Each cage $(20 \mathrm{~cm} \times 50 \mathrm{~cm})$ contained one potted sweet-orange seedling. The potted plants were maintained in the greenhouse at a temperature of $27^{\circ} \mathrm{C} \pm 1^{\circ} \mathrm{C}, 63 \% \pm 5 \%$ relative humidity.

\section{Lethal Concentration Estimation $\left(\mathbf{L C}_{50}\right)$}

Six suspensions $\left(10^{3}, 10^{4}, 10^{5}, 10^{6}, 10^{7}, 10^{8}\right.$ conidia $\left.\mathrm{mL}^{-1}\right)$ of the $M$. anisopliae strain $\mathrm{E}_{9}$ were tested against field-collected $O$. facialis to determine the $\mathrm{LC}_{50}$. The $\mathrm{LC}_{50}$ values were analysed using POLO-PC, a computer programme for probit analysis (14) based on the method of Finney (10).

\section{Conidial Viability}

Conidial concentrations were determined with an improved hemocytometer adjusted to $10^{7}$ conidia per milliliter by dilution with $0.1 \%$ Tween 20 . One milliliter of each suspension was removed and diluted to $10^{6}$ conidia $\mathrm{mL}^{-1}$ using $0.1 \%$ Tween 20 . Spore viability was determined by plating $100 \mu \mathrm{l}$ of the conidial suspensions on CM and counting colonies after $48 \mathrm{~h}$. Spore germination of $M$. anisopliae strain $\mathrm{E}_{9}$ exceeded $94 \%$ in all cases. All samples were adjusted to a final concentration of $10^{7}$ conidia $\mathrm{mL}^{-1}$.

\section{Bioassays}

Experiments were conducted with field-captured adult sharpshooters. Plots consisted of 10 sharpshooters, totaling 110 sharpshooters per treatment in a completely randomized design with 11 replicates. Insects were sprayed with a suspension of conidia at a $5 \times 10^{7}$ concentration conidia $\mathrm{mL}^{-1}$ with a viability of $94.9 \%$. Evaluations of the entomopathogenic action were done daily and after a period of 10 days. This experiment was conducted in a greenhouse with the same temperature and relative humidity cited above.

Dead sharpshooters were collected daily from the fungal treatment groups and the control groups and were tested to determine if mortality was due to infection. To confirm the identification of the primary pathogen, the sharpshooters were surface-sterilized by dipping them successively in $70 \%$ ethanol (10 $\mathrm{min}$ ), 2\% sodium hypochlorite solution ( $2 \mathrm{~min}$ ), and sterile water (40 seconds) and transferred with a camel-hair brush to Petri dishes containing CM media (19). These plates were sealed with parafilm and incubated at $27^{\circ} \mathrm{C} \pm 1^{\circ} \mathrm{C}$ for $7-14$ days. The dead sharpshooters were observed daily for the presence of external fungal structure such as hyphae and conidia. Dead sharpshooters with external hyphae and conidia were counted and only sharpshooters that showed fungal growth were considered to have died of infection, and only these counts were used to compute the pathogenicity of the fungal pathogens.

\section{Statistical Analysis}

The daily mortality values were accumulated during the experiments to allow $\mathrm{LT}_{50}$ (lethal time) calculation by Probit analysis using the Mobae computer program (13). The mite mortality data were submitted to analysis of variance using the F test and the means were compared by Tukey test $(P<0.05)$ using the Sanest (version 3.0) software package.

\section{RESULTS AND DISCUSSION}

The $M$. anisopliae strain $\mathrm{E}_{9}$ was tested against $O$. facialis sharpshooters at six suspensions of $10^{3}, 10^{4}, 10^{5}, 10^{6}, 10^{7}, 10^{8}$ conidia $\mathrm{mL}^{-1}$ and compared with controls. Each treatment and control group had 10 insects. The $M$. anisopliae strain $\mathrm{E}_{9}$ showed an $\mathrm{LC}_{50}$ of $1.2 \times 10^{6}$ conidia $\mathrm{mL}^{-1}$, varying from $7.7 \times 10^{5}$ to $2 \times 10^{6}$ conidia $\mathrm{mL}^{-1}$.

After 10 days, $96 \%$ mortality was observed for M. anisopliaeinfected $O$. facialis and $69 \%$ mortality was observed for noninfected $O$. facialis (negative control) (Fig. 1). Natural mortality was excluded because it happened in both treated and negative control groups. Mortality percentage was corrected using Abbott's formula (1). Corrected mortality was $87.1 \%$, which 


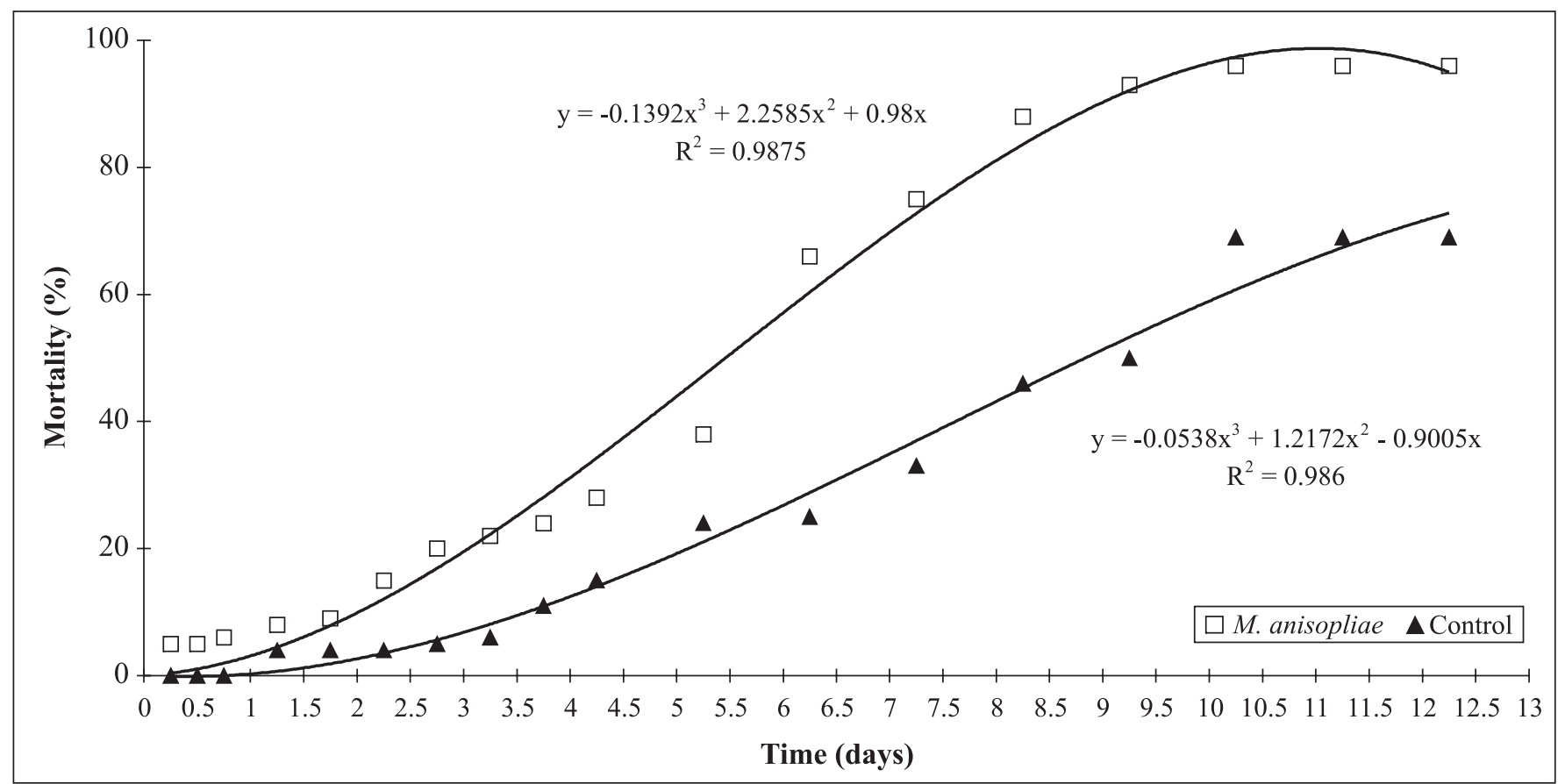

Figure 1. Mean cumulative mortality (\%) of Oncometopia facialis during an observation period of 12 days after application of the Metarhizium anisopliae suspension of $5 \times 10^{7}$ conidia $\mathrm{mL}^{-1}$ and the untreated control.

represented the percentage of dead sharpshooters due to action of M. anisopliae (Table 1).

Colonization of $O$. facialis by $M$. anisopliae occurred between $24 \mathrm{~h}$ and $72 \mathrm{~h}$. As typical in M. anisopliae-infected insects, the external fungal growth initiated on the intersegmental regions before spreading over the entire host. Fungal growths were especially concentrated on the head, thorax, and legs (Fig. 2).

The M. anisopliae $\mathrm{E}_{9}$ strain caused the highest total mortality $(87.1 \%)$ and the shortest $\mathrm{LT}_{50}(5$ to 6 days) (Table 1). These values are similar to those obtained by Kaya and Dara (21) for Homalodisca coagulata, a sharpshooter insect vector of $X$. fastidiosa in Pierce's Disease (2), using M. anisopliae isolates at a concentration of $5 \times 10^{8}$ conidia $\mathrm{mL}^{-1}$. In addition, Kanga $e t$ al. (19), working with $M$. anisopliae at $10^{8}$ conidia $\mathrm{mL}^{-1}$ and $H$. coagulata, verified a total mortality of $75 \%$ after 21 days and an $\mathrm{LT}_{50}$ value of 14 days. These authors also suggested the use of $M$. anisopliae in IPM to control $H$. coagulata. The results of the present study are promising because $87.1 \%$ mortality was obtained with a concentration of $10^{7}$ conidia $\mathrm{mL}^{-1}$ and $\mathrm{LT}_{50}$ of 5 to 6 days.

Chemical control with pyrethroid and neonicotinoid insecticides looks promising against immature and adult of sharpshooters $(34,35)$, but it is associated with residual contamination and interferes with biological control strategies (33). Jaramillo et al. (18) tested the use of combined applications of M. anisopliae with the neonicotinoid insecticide imidacloprid and did not observe colony growth inhibition for M. anisopliae in media containing this insecticide. These data reinforce that the use of insecticides to control $O$. facialis can be reduced when a fungus agent such as $M$. anisopliae is used as part of a biocontrol strategy.

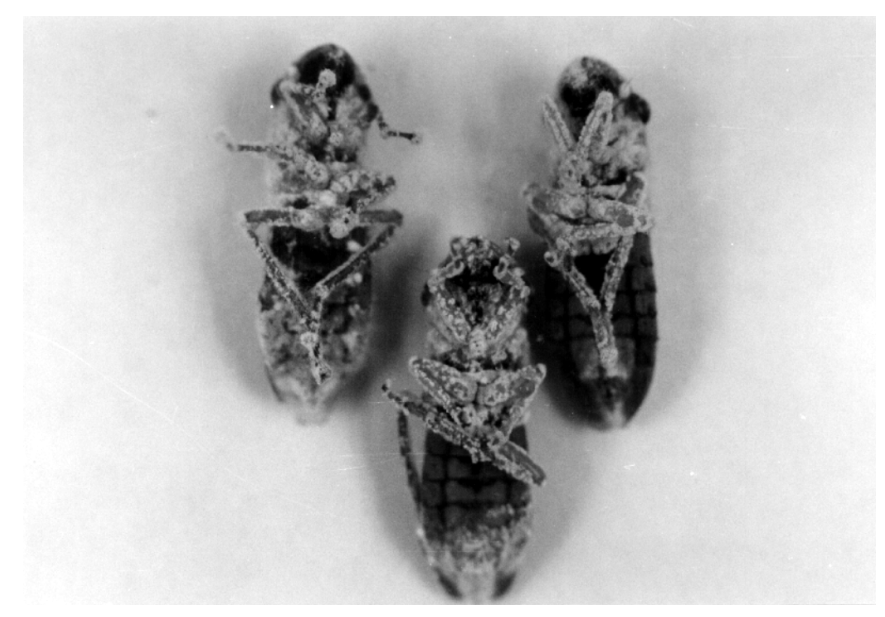

Figure 2. Metarhizium anisopliae, sprayed at suspension of 5 $\mathrm{X} 10^{7}$ conidia $\mathrm{mL}^{-1}$, emerging from dead glassy sharpshooters colleted from the treated samples after 6 days incubation. 
Table 1. Total mortality and confirmed mortality percentages of Oncometopia facialis by Metarhizium anisopliae strain $\mathrm{E}_{9}$ at suspension of $5 \times 10^{7}$ conidia $\mathrm{mL}^{-1}$

\begin{tabular}{ccccc}
\hline Observations & $\begin{array}{c}\text { Time } \\
(\text { days })\end{array}$ & $\begin{array}{c}\text { Mortality } \\
(\% \pm S E)\end{array}$ & $\begin{array}{c}\text { CV } \\
(\%)\end{array}$ & $\begin{array}{c}\text { Calculated } \\
\chi^{2}\end{array}$ \\
\hline 1 & 0 & 0 & 0 & 0 \\
2 & 0.25 & $5.0 \pm 0.02$ & 1.7 & $8.3^{*}$ \\
3 & 0.5 & $5.0 \pm 0.02$ & 1.7 & $8.3^{*}$ \\
4 & 0.75 & $6.0 \pm 0.02$ & 1.7 & $17.5^{*}$ \\
5 & 1.25 & $4.2 \pm 0.03$ & 3.1 & $2.8^{\text {ns }}$ \\
6 & 1.75 & $5.2 \pm 0.03$ & 3.4 & $3.5^{\text {ns }}$ \\
7 & 2.25 & $11.5 \pm 0.04$ & 4.1 & $9.8^{*}$ \\
8 & 2.75 & $15.8 \pm 0.05$ & 5.4 & $12.7^{*}$ \\
9 & 3.25 & $17.0 \pm 0.06$ & 6.2 & $9.9^{*}$ \\
10 & 3.75 & $14.6 \pm 0.07$ & 7.6 & $4.7^{*}$ \\
11 & 4.25 & $15.3 \pm 0.08$ & 8.7 & $3.9^{\text {ns }}$ \\
12 & 5.25 & $18.4 \pm 0.11$ & 12.9 & $3.0^{\text {ns }}$ \\
13 & 6.25 & $54.7 \pm 0.13$ & 17.5 & $22.8^{*}$ \\
14 & 7.25 & $62.7 \pm 0.13$ & 19.6 & $25.8^{*}$ \\
15 & 8.25 & $77.8 \pm 0.12$ & 20.6 & $40.2^{*}$ \\
16 & 9.25 & $86.0 \pm 0.10$ & 18.6 & $59.7^{*}$ \\
17 & 10.25 & $87.1 \pm 0.12$ & 25.0 & $25.0^{*}$ \\
18 & 11.25 & $87.1 \pm 0.12$ & 25.0 & $25.0^{*}$ \\
19 & 12.25 & $87.1 \pm 0.12$ & 25.0 & $25.0^{*}$ \\
\hline
\end{tabular}

Coefficient of variation $(\mathrm{CV}) ;{ }^{\text {ns }}$ not significant $(\mathrm{p}>0.05) ; *$ significant $(\mathrm{p}<0.05)$.

Little is known about predators, parasitoids, and pathogens that attack sharpshooter nymphs and adults (18). The results obtained in this study suggest that $M$. anisopliae can be successfully used for the control of $O$. facialis, indicating the importance of entomopathogenic fungi in an IPM strategy.

This is the first report that describes the use of M. anisopliae against $O$. facialis and demonstrates the potential to develop IPM strategies for this insect vector. However, additional studies are needed to provide a better understanding of host-pathogen interactions, and identify the factors that enhance or limit pathogenicity in sharpshooter populations under natural conditions.

\section{ACKNOWLEDGEMENTS}

The authors thank Coordenação de Aperfeiçoamento de Pessoal de Nível Superior - CAPES for the fellowship awarded to W.D. Pria Júnior and Fundo de Defesa da Citricultura FUNDECITRUS for financial support and Dr Thomas A. Miller (Entomology Department, University of California Riverside) for reviewing the manuscript.

\section{RESUMO}

\section{Avaliação do bioensaio de Metarhizium anisopliae (metchnikoff) sorokin (deuteromycota: hyphomycetes) contra Oncometopia facialis (signoret) (hemiptera: cicadellidae)}

A Clorose Variegada dos Citros (CVC) é uma doença economicamente importante e destrutiva no Brasil e é causada pela bactéria Xylella fastidiosa e transmitida por insetos vetores tal como Oncometopia facialis. Nesse estudo, a eficácia do fungo Metarhizium anisopliae em controlar o inseto vetor $O$. facialis foi estudada em condições de bioensaio. Nesse bioensaio, insetos foram pulverizados com uma suspensão de $5 \times 10^{7}$ conídio $\mathrm{mL}^{-1}$. Insetos-adultos capturados no campo foram tratados em grupos de 10, em um total de 11 replicatas por tratamento. Diferenças significativas entre a mortalidade natural e a mortalidade dos insetos tratados com o fungo foram observadas em 6 dias após a inoculação $(P<0.05)$. Estas diferenças significativas aumentaram antes do décimo dia após o tratamento. O fungo causou uma mortalidade de $87,1 \%$, com uma $\mathrm{LT}_{50}$ variando entre 5 e 6 dias. $\mathrm{ALC}_{50}$ foi de $1,2 \times 10^{6}$ conídio $\mathrm{mL}^{-1}$, variando de $7,7 \times 10^{5}$ a $2 \times 10^{6}$ conídio $\mathrm{mL}^{-1}$. Estes resultados mostraram que o vetor $O$. facialis foi susceptível a ação entomopatogênica de $M$. anisopliae em condições controladas durante o bioensaio.

Palavras-chave: controle microbiano, entomopatógeno, Clorose Variegada dos Citros (CVC), bioensaio

\section{REFERENCES}

1. Abbott, W.S. (1925). A method of computing the effectiviness of an insecticide. J. Economics Entomol., 18, 265-267.

2. Almeida, R.P.P.; Purcel, A.H. (2003). Transmission of Xylella fastidiosa to grapevines by Homalodisca coagulata (Hemiptera: Cicadellidae). J. Econ. Entomology, 96, 264-271.

3. Alves, S.B.; Almeida, J.E.M.; Moino JR., A.; Alves, L.F.A. (1998). Técnicas de laboratório. In: Alves, S.B. (ed) Controle Microbiano de Insetos. FEALQ, Piracicaba, Brasil, p.637-771.

4. Brlansky, R.H.; Damsteegt, V.D.; Hartung, J.S. (2002). Transmission of the citrus variegated chlorosis bacterium Xylella fastidiosa with the sharpshooter Oncometopia nigricans. Plant Dis., 86, 1237-1239.

5. Chang, C.J.; Garnier, M.; Zreik, L.; Rossetti, V.; Bové, J.M. (1993). Culture and serological etection of xylem-limited bacterium causing citrus variegated chlorosis and its identification as a strain of Xylella fastidiosa. Curr. Microbiol., 27, 137-142.

6. Charnley, A.K. (1989). Mechanisms of fungal pathogenesis in insects. In: Whipps, J.M.; Lumsden, R.D. (eds). Biotechnology of Fungi for Improving Plant Growth. Cambridge University Press, Cambridge, UK, p.85-125.

7. Coletta-Filho, H.D.; Takita, M.A.; Souza, A.A.; Aguilar-Vildoso, C.I.; Machado, M.A. (2001). Differentiation of strains of Xylella fastidiosa by a variable number of tandem repeat analysis. Appl. Environ. Microbiol., 67, 4091-4095.

8. de Souza, A.A.; Takita, M.A.; Pereira, E.O.; Coletta-Filho, H.D.; Machado, M.A. (2005). Expression of pathogenicity-related genes 
of Xylella fastidiosa in vitro and in planta. Curr. Microbiol., 50, 223-228.

9. Destéfano, R.H.R.; Bechara, I.J.; Messias, C.L.; Piedrabuena, A.E. (2005). Effectiveness of Metarhizium anisopliae against immature stages of Anastrepha fraterculus fruitfly (Diptera: Tephritidae). Braz. J. Microbiol., 36, 94-99.

10. Finney, D. (1971). Probit Analyses. Cambridge University Press, Cambridge, p.333.

11. Freire, L.L.C.; Costa, A.B.L.; Goés, L.B.; Oliveira, N.T. (2001). DNA polymorphism and total protein in mutants of Metarhizium anisopliae var. anisopliae (Metsch.) Sorokin strain $\mathrm{E}_{9}$. Braz. J. Microbiol., 32, 93-97.

12. French, W.J.; Kitajima, E.W. (1978). Occurrence of plum leaf scald in Brazil and Paraguay. Plant Dis. Reptr., 62, 1035-1038.

13. Haddad, M.L.; Moraes, R.C.B.; Parra, J.R.P. (1995). Modelos bioestatísticos aplicados á entomologia (MOBAE). Editora ESALQ/ USP, Piracicaba, São Paulo.

14. Haddad, M.L. (1998). Utilização do Polo-PC para análise de Probit. In: Alves, S.B. (ed). Controle microbiano de insetos. Fealq, Piracicaba, Brasil, p.999-1013.

15. Hartung, J.S.; Beretta, J.; Bralansky, R.H.; Spisso, J.; Lee, R.F. (1994). Citrus Variegated Chlorosis bacterium: axenic culture, pathogenicity, and serological relationships with other strains of Xylella fastidiosa. Phytopathology, 84, 591-597.

16. Hartung, J.S. (2004). Pierce's disease and Xylella fastidiosa. In: Goodman, R.M. (ed). Encyclopedia of Crop and Soil Science. Marcel Dekker, New York, USA, p.928-930.

17. Hopkins, D.L.; Purcell, A.H. (2002). Xylella fastidiosa: Cause of Pirece's disease of grapevine and other emergent diseases. Plant Dis., 86, 1056-1066.

18. Jaramillo, J.; Borgemeister, C.; Ebssa, L.; Gaigl, A.; Tobón, R.; Zimmermann, G. (2005). Effect of combined applications of Metarhizium anisopliae (Metsch.) Sorokin (Deuteromycotina: Hyphomycetes) strain CIAT 224 and different dosages of imidacloprid on the subterranean burrower bug Cyrtomenus bergi Froeschner (Hemiptera: Cydnidae). Biol. Control, 34, 12-20.

19. Kanga, L.H.B.; Jones, W.A.; Humber, R.A.; Boyd JR, D.W. (2004). Fungal pathogens of the glassy-winged sharpshooter Homalodisca coagulata (Homoptera: Cicadellidae). Fla. Entomol., 87, 225-228.

20. Kava-Cordeiro, V.; Queiroz, M.V.; Pizzirani-Kleiner, A.A.; Azevedo, J.L. (2005). Pulsed field gel electrophoresis reveals chromosome length and number differences in brazilian strains of Metarhizium anisopliae. Braz. Arch. Biol. Technol., 48, 1-6.

21. Kaya, H.K.; Dara, S.K. (2004). Microbial control of the glassywinged sharpshooter with entomopathogenic fungi. Proceedings of the Pierce's Disease Research Symposium, San Diego, CA, p.349.

22. Khan, A.R.; Selman, B.J. (1989). Nosema spp. (Microspore: Microsporida: Nosematidae) of stored-product Coleoptera and their potential as microbial control agents. Agric. Zool. Rev., 3, 193-223.

23. Messias, C.L.; Azevedo, J.L. (1980). Parasexuality in the Deuteromycete Metarhizium anisopliae. Trans. Br. Mycol. Soc., 75, 473-477.

24. Miller, C.D.; Rangel, D.; Braga, G.U.L.; Flint, S.; Kwon, S-I; Messias, C.L.; Roberts, D.W.; Anderson, A.J. (2004). Enzyme activities associated with oxidative stress in Metarhizium anisopliae during germination, mycelial growth, and conidiation and in response to near-UV irradiation. Can. J. Microbiol., 50, 41-49.

25. Paradela Filho, O.; Sugimori, M.H.; Ribeiro, I.J.A.; Garcia Jr., A.; Beretta, M.J.G.; Harakawa, R.; Machado, M.A.; Machado, F.F.; Rodrigues Neto, J.; Beriam, L.O.S. (1995). Primeira constatação em cafeeiro no Brasil da Xylella fastidiosa causadora da clorose variegada dos citros. Laranja, 16, 135-136.

26. Parella, P.M.; Lewis, T. (1997). Integrated pest management (IPM) in field crops. In: Lewis, T. (ed). Thrips as Crop Pests. CAB International, Wallingford, UK, p.599-614.

27. Riba, G.; Azevedo, J.L.; Messias, C.L.; Silveira, W.D.; Tuveson, R. (1985). Studies of the inheritance of virulence in the entomopathogenic fungus Metarhizium anisopliae. J. Invert. Pathol., 46, 20-25.

28. Roberto, S.R.; Coutinho, A.; Lima, J.E.O.; Miranda, V.S.; Carlos, E.F. (1996). Transmissão de Xylella fastidiosa pelas cigarrinhas Dilobopterus costalimai, Acrogonia terminalis e Oncometopia facialis em citros. Fitop. Bras., 21, 517-518.

29. Roessler, Y. (1989). Insecticidal bait and cover sprays. In: Robinson, A.S.; Hoopher, G. (eds). Fruit flies: their biology, natural enemies and control. World Crop Pests. Elsevier, Amsterdam, The Netherlands, p.329-336.

30. Rossetti, V.; de Negri, D. (1990). Clorose Variegada dos Citros no Estado de São Paulo. Laranja, 11, 1-14.

31. Simpson, A.J.; Reinach, F.C.; Arruda, P.; Abreu, F.A.; Acencio, M.; Alvarenga, R.; Alves, L.M.; Araya, J.E.; Baia, G.S.; Baptista, C.S.; Barros, M.H.; Bonaccorsi, E.D.; Bordin, S.; Bove, J.M.; Briones, M.R.; Bueno, M.R.; Camargo, A.A.; Camargo, L.E.; Carraro, D.M.; Carrer, H.; Colauto, N.B.; Colombo, C.; Costa, F.F.; Costa, M.C.; Costa-Neto, C.M.; Coutinho, L.L.; Cristofani, M.; Dias-Neto, E.; Docena, C.; El-Dorry, H.; Facincani, A.P.; Ferreira, A.J.; Ferreira, V.C.; Ferro, J.A.; Fraga, J.S.; Franca, S.C.; Franco, M.C.; Frohme, M.; Furlan, L.R.; Garnier, M.; Goldman, G.H.; Goldman, M.H.; Gomes, S.L.; Gruber, A.; Ho, P.L.; Hoheisel, J.D.; Junqueira, M.L.; Kemper, E.L.; Kitajima, J.P.; Krieger, J.E.; Kuramae, E.E.; Laigret, F.; Lambais, M.R.; Leite, L.C.; Lemos, E.G.; Lemos, M.V.; Lopes, S.A.; Lopes, C.R.; Machado, J.A.; Machado, M.A.; Madeira, A.M.; Madeira, H.M.; Marino, C.L.; Marques, M.V.; Martins, E.A.; Martins, E.M.; Matsukuma, A.Y.; Menck, C.F.; Miracca, E.C.; Miyaki, C.Y.; Monteriro-Vitorello, C.B.; Moon, D.H.; Nagai, M.A.; Nascimento, A.L.; Netto, L.E.; Nhani, A. Jr.; Nobrega, F.G.; Nunes, L.R.; Oliveira, M.A.; Oliveira, M.C.; Oliveira, R.C.; Palmieri, D.A.; Paris, A.; Peixoto, B.R.; Pereira, G.A.; Pereira, H.A. Jr.; Pesquero, J.B.; Quaggio, R.B.; Roberto, P.G.; Rodrigues, V.M.; Rosa, A.J.; Rosa, V.E. Jr.; Sa, R.G.; Santelli, R.V.; Sawasaki, H.E.; Silva, A.C.; Silva, A.M.; Silva, F.R.; Silva, W.A. Jr.; Silveira, J.F.; Silvestri, M.L.; Siqueira, W.J.; Souza, A.A.; Souza, A.P.; Terenzi, M.F.; Truffi, D.; Tsai, S.M.; Tsuhako, M.H.; Vallada, H.; Van Sluys, M.A.; Verjovski-Almeida, S.; Vettore, A.L.; Zago, M.A.; Zatz, M.; Meidanis, J.; Setubal, J.C. (2000). The genome sequence of the plant pathogen Xylella fastidiosa. Nature, 406, 151-157.

32. Valadares-Inglis, M.C.; Azevedo, J.L. (1997). Amylase and protease secretion in recombinant strains of Metarhizium anisopliae var. anisopliae following parasexual crosses. Rev. Braz. J. Genet., 20, 171-175.

33. Varela, L.G.; Smith, R.J.; Phillips, P.A. (2001). Pierce's Disease. Agriculture and Natural Resources Publication 21600. University of California, Davis.

34. Yamamoto, P.T.; Felippe, M.R.; Caetano, A.C.; Sanches, A.L.; Almeida, E.J.; Nociti, L.A.S. (2002). Eficiência de inseticidas neonicotinóides aplicados via tronco no controle de Oncometopia facialis (Signoret) (Hemiptera: Cicadellidae) em mudas de laranjeira 'Pêra'. Laranja, 23, 77-100.

35. Yamamoto, P.T.; Felippe, M.R.; Nociti, L.A.S.; Montesino, L.H.; Coelho, J.H.C. (2003). Uso de acetamiprid no controle da cigarrinha em citros. Laranja, 24, 337-351. 